\title{
6. Ireland after the Great Recession: Convergence or divergence?
}

\section{Philip J. O'Connell}

\section{HISTORICAL CONTEXT}

There is substantial evidence of Irish convergence with European standards in recent decades. In economic terms, much of that convergence took place in the 1990s. In terms of gross domestic product (GDP) per capita - often used in popular accounts - Ireland began the 1990s at about 60 per cent of the then European average, ${ }^{1}$ but after exceptionally rapid economic growth, it ended the decade at about 120 per cent of the average. This does not, however, mean that Ireland had become one of the richest countries in the world at the beginning of this century. Foreign direct investment (FDI) plays a very substantial role in Irish economic activity and in its measured growth rates. As a result, an unusually large proportion of national product flows out of Ireland to foreign investors. To take an alternative measure of output, gross national income - which is not so influenced by FDI flows and arguably provides a better measure of income available to Irish residents - grew rapidly, from about 20 per cent below the Organisation for Economic Co-operation and Development (OECD) average in 1995 to about 4 per cent above it in 2002 (Nolan and Maitre 2017). Even this more modest approach still suggests a convergence process, however, to around the European average in terms of per capita income.

We also see convergence in employment. The Irish employment rate increased from 52 per cent of the resident population aged 15-64 years in 1993, at a time when the EU average was 60 per cent, to just over 69 per cent in 2007, at which point it exceeded the EU average of 67 per cent (Eurostat). Female employment also increased rapidly over this period, from 39 per cent of the population in 1993, when the European Union (EU) average was 48 per cent, to over 60 per cent in 2007, slightly ahead of the EU average of 59 per cent, thus converging with both the male Irish rate and the European average.

Explanations for the rapid growth in the economy and employment over the 1990s - which came to be known as the Celtic Tiger boom - include a delayed-convergence narrative that attributes delayed economic development to poor public policy-making in the initial decades of Irish independence (FitzGerald 2000), as well as accounts that emphasise the important role of FDI in developing Ireland as an export platform for high value-added production in manufacturing and, more laterally, services (Barry and Bergin 2017). The role of social dialogue in Ireland's belated development and convergence with the European core is disputed. Some explanations of the boom emphasise the role of Irish Social Partnership institutions, in which government, employers, unions and the voluntary sector negotiated national agreements on wages and a range of economic and social policies. Social partnership is argued to have facilitated rapid growth and 
underpinned competitiveness by linking wage increases in the dynamic and highly productive FDI-exporting firms to the lower wages and productivity levels in the less dynamic domestic sector (Baccaro and Simoni 2002; McGuinness et al. 2010). Honohan and Walsh (2002) are more sceptical of the impact of social partnership, although they do acknowledge the coincidence between the development of social partnership and the improvement in competitiveness, which gave rise to the economic boom and employment growth. A crucial feature of the early social partnership deals agreed between the peak organisations of business and labour, represented by the Irish Congress of Trade Unions (ICTU), was the exchange of reductions in taxes on employees for wage restraint. Low taxes on income as well as low corporation tax to attract mobile FDI combined to curtail expansion of the welfare state in Ireland and limit spending on health, education and housing. This led to the unusual combination of national social dialogue through the social partnership institutions with a 'liberal' welfare regime. Typical of liberal welfare regimes, Irish welfare policies are dominated by market provision, with low rates of social provision and an emphasis on cash transfers that are targeted and largely allocated on a means-tested basis. This residual approach to welfare policy was not a result of social partnership but reflected a long-standing characteristic of Irish social policy. More broadly, within the 'varieties of capitalism' approach, Ireland is regarded as a liberal market economy, with competitive market processes, low rates of unionisation, decentralised collective bargaining, and high levels of wage and income inequality, although the state is much more active in attracting FDI than might be anticipated in the ideal-typical liberal market economy. The Irish labour market is considered to be flexible, with weak employment protection legislation and low and declining union density.

This brief historical overview would suggest that, while there were strong elements of convergence between Ireland and European standards of living before the Great Recession (hereafter the Recession), the Irish model nevertheless differed in important respects from many of its European neighbours. This chapter explores the extent to which Ireland may have converged with, or diverged, from other European patterns in the course of its recent experience of recession and recovery.

The Recession and the unexpectedly rapid recovery are described below. This is followed by a discussion of the main trends in social dialogue, which outlines the framework of Irish Social Partnership and industrial relations processes, tracks the long-run decline in trade union membership and reviews changes to state institutions governing collective bargaining and wage-setting. The next section explores labour market outcomes over the past decade, a period that encompasses the boom, the Recession and the recent recovery, in a context of declining union membership and shifting arrangements for collective bargaining. That discussion, which focuses on trends in employment and unemployment, as well as changes in job quality and in atypical working, includes a comparison of the Irish experience with a range of countries that also experienced deep economic and financial crises (Greece, Spain, Latvia and Portugal), as well as countries that serve as examples of differing welfare regimes (Belgium, Sweden and the United Kingdom). Shifts in welfare policy and inequality are also considered. The chapter includes a case study of young people in the Irish labour market. Young people were hit particularly hard by the Recession in Ireland, and their participation in the recovery has been limited in both the quantity and quality of jobs. This can be attributed, at least in part, to the rise in non-union jobs and the decline in collective bargaining coverage for the jobs that 
young people are entering. Whether this represents a case of declining social dialogue leading to divergence from European norms, or to downward convergence, remains to be seen.

\section{THE GREAT RECESSION AND RECOVERY IN IRELAND}

There were five key elements to the crisis that erupted on the Irish state and economy, beginning in 2008: the bursting of the property bubble; the banking collapse; the contraction in economic activity; the fiscal crisis of the state; and mass unemployment. Following a long and sustained period of inflation in property prices over the course of the previous decade, and a dramatic increase in household debt, the Irish property bubble burst, with prices falling by over 40 per cent in the three years after 2007.

The property bubble had been facilitated by lax lending practices overseen by 'lighttouch' regulation that followed an international pattern of withdrawal of the state from banking supervision. Irish banks were exposed not only to the domestic residential and property bubbles, but also to shifts in the international economy because Irish banks had borrowed profligately abroad to speculate in both domestic and international markets. In the aftermath of the Lehmann Brothers collapse, two Irish banks failed (Anglo Irish Bank and Irish Nationwide Building Society). Another, Allied Irish Bank, was fully taken over by the state and the only other major player, Bank of Ireland, required substantial recapitalisation by the state.

The Irish economy moved into recession in the first half of 2008. Gross national product contracted by 3.5 per cent in 2008 and by almost 10 per cent in 2009. By 2010, GNP per capita had contracted by almost one-fifth of its level in 2007 , before the crisis. There was further contraction in 2011 and growth remained extremely sluggish through 2013. As the economy contracted, employment fell by about 14 per cent over the three years from 2008 to 2011. Unemployment increased from less than 5 per cent at the beginning of 2008 to over 15 per cent in 2012. Long-term unemployment increased very rapidly as the recession took hold and persisted. In response to the labour market decline emigration increased, immigration declined and Ireland returned to net emigration in 2009 for the first time since the mid-1990s.

Two factors underlay the fiscal crisis of the Irish state: the contraction of tax revenues and the cost of the bank crisis. State revenues contracted with lower economic activity, less employment and a sharp decline in the taxes on property transactions upon which the state had become heavily dependent during the property bubble. The general government deficit went from surplus to a deficit of 7 per cent of GDP in 2008, and over 12 per cent in 2009. In September 2008, the government took the momentous step of guaranteeing almost all Irish bank liabilities and subsequently injected substantial funds to recapitalise the banks with public funds. The national debt increased from 25 per cent of GDP in 2007 to 120 per cent in 2011, about one-third of which was a result of the bank bailout.

Confronting fiscal crisis in 2009, the Irish government embarked on a severe austerity programme to restore balance to the public finances, including spending cuts, tax increases and public-sector pay cuts. The austerity package, designed to reduce the deficit to 3 per cent by 2015 , entailed an adjustment of $€ 32$ billion, consisting of $€ 20.5$ billion in spending cuts and $€ 11.5$ billion in tax increases. The cumulative effects of this 
austerity package represented almost 20 per cent of GDP. Alternatives to austerity were proposed by the ICTU, which advocated a more Keynesian approach to maintaining demand by sustaining pay levels, honouring negotiated pay increases, increasing public infrastructural investment and extending the period over which the budget deficit would be reduced (Roche et al. 2017). That approach won little support from government or employers and was largely overtaken by events: the collapse of Social Partnership in 2009 and the bankruptcy of the Irish state in 2010. By 2010, despite the austerity policies, the state was unable to borrow on international financial markets and had to avail itself of a financial assistance programme from the Troika, comprising the European Commission, the European Central Bank (ECB) and the International Monetary Fund (IMF). In the initial phase of the austerity package, 2008-10, before the arrival of the Troika, adjustments amounting to almost $€ 15$ billion or 10 per cent of GDP were achieved. The second half of the austerity programme, of the same order of magnitude, was implemented over 2011-15, the first three of those years under the supervision of the Troika.

The Irish economy emerged from recession in 2012 and grew strongly from 2013 achieving 'the strongest post-crisis output recovery in the OECD' (OECD 2018, p.2). Unemployment fell, to 5 per cent of the labour force in 2018, and the government's underlying primary fiscal deficit was 2 per cent of GDP in 2012, remaining below 1 per cent for the following five years.

Ireland's dramatic recovery has led it to be regarded as a 'poster child' for economic regeneration from fiscal austerity. The Irish case has been hailed by the Troika institutions as evidence that where a country stuck closely to prescribed austerity measures, the fiscal disciplines and structural changes involved could provide a platform for stability and a return to growth and prosperity. However, Kinsella (2017, p. 58) suggests that Ireland is best seen less as a 'poster child' than as a 'beautiful freak', whose experience of austerity and recovery reflects a very specific set of conditions that differ markedly from other countries forced to seek bailout support. Troika assistance to Irish banks, allied with restructuring and regulatory reform, contributed to financial stability and restoration of international confidence. Roche et al. (2017) argue that fiscal consolidation was necessary, but the key driver of economic recovery was the export performance of multinational firms, trading in international markets in major economies that had been less seriously affected by the Recession and that had recovered more rapidly. Ireland's export performance more than offset the serious dampening effects of austerity on domestic demand. Other features specific to the Irish case that were also critical in contributing to stability and recovery included the consensus among the main Irish political parties on the need for austerity, and a degree of continuity in social dialogue between employers and unions. Public service trade unions contributed to stability by accommodating fiscal retrenchment and accepting significant cuts in pay and employment. This avoided the industrial conflict experienced by other countries implementing austerity cuts. Peaceable industrial relations were maintained across the private sector, where cuts in nominal pay were far from widespread and employers focused on cutting working time and employment. 


\section{SOCIAL DIALOGUE}

\subsection{Industrial Relations Framework and Process}

Centralised collective bargaining dominated industrial relations in Ireland from 1987 until the economic crisis in 2008. The Irish model of social partnership had emerged in response to the recession and fiscal crisis of the 1980s. Seven national Social Partnership agreements were negotiated over this period, setting wages through nationally negotiated pay deals every three years or so. National agreements set benchmarks to be followed voluntarily across the economy and non-unionised firms tended to shadow the national benchmarks (McGuinness et al. 2010). The initial tripartite agreements represented an exchange of tax reductions for wage moderation designed to enhance competitiveness and thus increase employment. Later agreements expanded the coverage of Social Partnership to general economic, fiscal and social policy, and included a wide range of actors, among them non-governmental organisations which played an important role in delivering elements of social policy in education, health and social services. As outlined in section 1, the series of Social Partnership agreements is considered by many commentators to have facilitated the industrial peace and gains in competitiveness that ushered in a period of economic growth that resulted in economic convergence with the developed economies of the European core. Over the two decades from 1987 to 2007 - a period that saw seven national-level Social Partnership agreements - real wages increased by 35 per cent averaged across all industries (CSO 2017a).

The social partners negotiated a National Wage Agreement - 'Towards 2016: Review and Transitional Agreement 2008/2009' (T16) - immediately before the economic collapse in 2008. T16 agreed a pay-pause for 11 months in the public sector and three in the private sector, followed by a 6 per cent increase over the following 18 months. The agreement also included government commitments to improve collective bargaining and employment rights (Regan 2012). However, from the onset of the crisis in 2008 the state retreated from the tripartite social partnership system and as an employer reneged on the T16 wage deal. The vast majority of private sector employers followed suit, signalling a shift from national to local enterprise level bargaining (Hickland and Dundon 2016; Roche 2017). Cuts in public service pay and numbers were central to the fiscal consolidation policies adopted in response to the crisis after 2009. Three pay cuts were implemented across the public service in 2009, 2010 and 2013: the 2009 cut entailed a public service pension levy averaging 7 per cent and the two subsequent pay cuts averaged 6 per cent each, although all three cuts were progressive, cutting more from those on higher incomes (Roche 2017). Overtime rates were also cut, and premium salary payments reduced. In an effort to secure a long-run reduction in pay rates, all new entrants to the public service from 2010 were appointed at salary scales that had been reduced by 10 per cent of the scales applying to incumbents (O'Connell 2013). Total numbers working in the public sector fell by 10 per cent between 2008 and 2013 and the total public service pay bill fell by almost 18 per cent between 2009 and 2013 (DPER 2014).

In the private sector, many employers responded to the crisis by freezing wages and a minority cut basic pay levels - about half were in the freezing faction and a quarter in the cutting camp in 2009 (Roche 2017). Employers were more likely to lay workers off, or to cut their working hours. Private sector employment contracted by 16 per cent between 
2009 and 2011 and working time was also cut. So, while hourly wages remained virtually static, average weekly wages across the private sector fell by about 3.5 per cent between 2009 and 2011, but then started to recover slowly, and fully by 2015 (O'Connell 2013; Roche 2017).

The initial cuts in 2009 were imposed by emergency legislation, without recourse to collective bargaining. In spring 2010 the public-sector unions and the government reengaged in dialogue and the Public Service Agreement (2010-14) (colloquially known as the Croke Park Agreement, referring to the conference venue at the football stadium) was negotiated between the Irish government and the unions. The government undertook not to implement any further pay cuts for four years and to demand no compulsory redundancies. The agreement also provided for substantial reduction in public service numbers, largely via voluntary redundancies, revised work practices, organisational restructuring and redeployment of staff across the public sector, and an industrial peace clause.

The Croke Park Agreement was formally endorsed in June 2010 by the ICTU. The rationale on the union side was that the agreement represented 'an avenue to save people's jobs' (MacCarthaigh 2017, p. 171). A significant minority - seven trade unions representing some teachers, nurses, lower paid public servants and others - voted against the agreement, but most subsequently accepted it.

The Public Service Stability Agreement (2013-16), popularly known as the Haddington Road Agreement, negotiated between the government and public-sector trade unions, imposed additional pay cuts, progressively from 5.5 per cent of salaries over $€ 65000$ to 10 per cent of earnings of over $€ 100000$ and increased working hours (about two hours per week), but also provided for the restoration of these pay cuts after 2016. The agreement also sought further flexibility from workers on redeployment, performance management, work-sharing arrangements and workforce restructuring. The first draft of the Haddington Road Agreement had been rejected by a majority of unions, and the final agreement was accepted after the government threatened to legislate for cuts in the absence of an agreement (MacCarthaigh 2017). The Lansdowne Road Agreement (2013-18) was negotiated in a context of economic recovery and an improvement in the fiscal outlook. Trade unions pressed for repeal of the cuts imposed under the emergency legislation and the Haddington Road deal, increases in public service pay and an end to the moratorium on recruitment. The new agreement represented an extension of the Haddington Road Agreement and provided for restoration of pay cuts and reductions in the public-sector pensions levy, although the extent of any public-sector pay increases were constrained by new European fiscal rules, which required that any increases in public spending be offset by tax increases, which faced resistance from the electorate.

A particular feature of the series of wage cuts imposed in the public sector during the Irish crisis, and of the series of collective agreements surrounding those cuts, was the differential treatment of new entrants. From 2010, in an effort to secure a long-lasting structural reduction in pay rates, all new entrants to the public sector were to be appointed at salary scales reduced by 10 per cent relative to the scales applying to incumbents.

Since the recovery, public-sector unions have sought to restore the pay-cuts imposed during the crisis and to unravel the differential pay scales between new entrants and incumbents. The Haddington Road Agreement provided for the reintegration of the new, lower scales with the older, higher scales, and added two additional points at entry level. This means that public-sector workers are now on the same incremental scales, but the 
new entrants came in at a lower entry level, entailing a cumulative loss of earnings until they reach the top of the scale. Young teachers were hit particularly hard by the pay cuts as they lost additional allowances (of up to five incremental points on the salary scale) for higher education degrees, while their older colleagues retained those allowances, and these have not been restored to the younger teachers. Not all public-sector unions signed up to the series of collective agreements on wages and working arrangements. Those that resisted the wage cuts, particularly teaching unions, have seen their members threatened with being left behind in elements of pay restoration, including payment of increments. Here we find an example of more militant unions and their members continuing to suffer from cuts that have been returned to those of more compliant unions. This has given rise to the continued controversy of unequal pay for younger teachers. It has also led to tensions between teacher unions and has weakened their bargaining position.

Notwithstanding the more robust relationship between government-as-employer and public-sector unions, the series of agreements after 2009 represent some degree of continuity in social dialogue that delivered pay cuts and reductions in public-sector numbers, as well as reforms in work practices and redeployment, while providing job security for public servants on permanent contracts. They also provided for pay restoration when macroeconomic and fiscal conditions improved. Hickland and Dundon (2016) argue that the agreements indicate the utility of maintaining social dialogue as a problem-solving response to economic crisis. Nevertheless, bitter disputes emerged in the case of unions, particularly in the education sector, that did not sign up to the agreements and whose members have lost some ground in the restoration process.

Collective bargaining in the private sector shifted to local and enterprise level after the IBEC withdrew from the T16 national pay agreement. The remnants of social partnership in this sector took the form of a protocol between the IBEC and the ICTU for the 'Orderly conduct of industrial relations and local bargaining in the private sector', which was agreed in 2010 and renewed in 2013 as a mechanism to promote industrial peace (Hickland and Dundon 2016). Regan (2012) argues that the accord is premised on a strategy to sustain employment and that it has a symbolic function of demonstrating to the state dispute resolution authorities that the erstwhile social partners still recognise each other. During the Recession, from 2009 to about 2011, unions mainly engaged in decentralised firm-level concession bargaining with private-sector employers, exchanging concessions on pay, conditions and work practices for commitments to protect jobs (Roche 2017). Unions were mainly concerned with protecting jobs in the face of the sharp contraction in private-sector employment: there was little scope for pay increases except in the most resilient and profitable firms (Roche and Teague 2015).

Hickland and Dundon (2016) document how the Services Industrial Professional and Technical Union (SIPTU) developed an enterprise-level campaign in 2011 in pursuit of modest pay rises of about 2 per cent. The ' 2 per cent strategy' entailed bargaining for modest incremental increases with carefully targeted profitable enterprises, mainly in pharmaceuticals and electronics. The strategy was to negotiate directly between the union and the company without the involvement of outside bodies, including the IBEC and the Labour Relations Commission. Roche and Gormley (2018) argue that this represented a form of pattern bargaining in which deals reached in the buoyant and profitable export sectors spread progressively beyond those sectors into engineering, large retail chains, construction supply, banking and state-owned commercial enterprises 
as economic recovery gathered pace. The 2 per cent target originally set out by the SIPTU was respected by other large unions, including Unite, the Technical Engineering and Electrical Union (TEEU) and Mandate. Roche and Gormley also argue that the 2 per cent strategy took account of wage rises in Germany, as well as the ECB target of 2 per cent inflation. This attempt to match wage increases to wage movements in Germany and to European inflation would suggest that the effect of industrial relations practices in this phase was to increase the extent of convergence with European trends. The 2 per cent strategy was regarded by unions as providing for modest pay increases and protecting jobs while also supporting competitiveness. By 2014, the 2 per cent strategy had delivered over 220 collective agreements covering 'upwards of 50,000 workers' (Hickland and Dundon 2016, p. 228).

Much of the international literature contends that one effect of the Recession was to accelerate trends towards decentralisation of pay-bargaining in a disorganised manner that compromised the capacity for unions to represent their members (Visser et al. 2015; Koukiadaki et al. 2016). Ireland was one of the European countries that suffered deep recession and fiscal contraction, entered a programme of financial support from the Troika and saw a decline in collective bargaining coverage, leading to what Visser et al. (2015, p. 9, table) terms 'disorganized decentralization' of collective bargaining. However, the resumption of collective bargaining across most of the public sector, and the development of pattern bargaining in the private sector in the context of economic recovery, suggests some continuity, and a degree of coordination in social dialogue. Thus, Roche and Gormley (2017) argue that the conduct of Irish industrial relations did not follow the path expected by commentators who saw disorganised decentralisation as the outcome of recession and weakening of trade unions. Rather, they argue that pay bargaining in Ireland after the crisis represents a case of 'orderly decentralisation' (Roche and Gormley 2017 , p.4) and then to new forms of coordination based on pattern bargaining in the private sector and sectoral bargaining in the public sector.

\subsection{Trade Union Membership}

Given the intensity of the economic crisis and the scale of job losses, it is hardly surprising that trade unions were weakened by the crisis. However, union density has been in steady decline in Ireland for decades. Walsh shows that union density declined from about 46 per cent of employees in 1994 to about 27 per cent in 2008. Figure 6.1 shows that union density fell from 38 per cent in 2003 to 32 per cent in 2007, and then recovered to 34 per cent in 2009. Thereafter, in the context of economic contraction and declining employment, the decline accelerated, to a low point of 27 per cent in 2014. Collective bargaining coverage rates have followed this downwards trajectory, from 46 per cent in 2003 to 39 per cent in 2008 and 32 per cent in 2013 (International Labour Organization, ILOSTAT). These declines in trade union density and coverage prior to the crisis may have been partially due to the tendency for nationally agreed pay agreements in the Social Partnership system to function as benchmarks for pay trends across the entire labour market, thus creating a free-rider problem in which individual workers benefit from the collective bargaining organised by unions of which they may not be members.

The overall pattern conceals important differences between the public and private sectors in both level and trends over time in union membership. In the private sector, union 


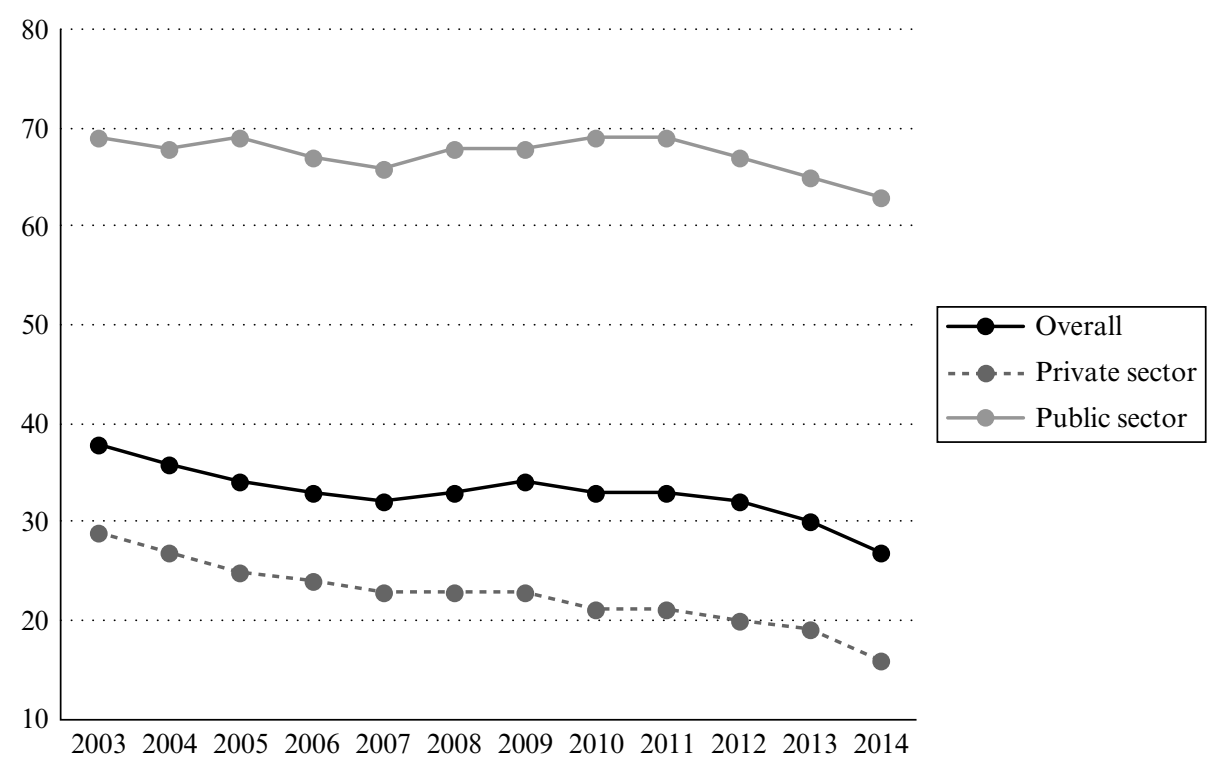

Source: Roche (2017), derived from Walsh (2014).

Figure 6.1 Trends in union density, Ireland, 2003-14

density is low, never higher than 30 per cent in the twenty-first century. Moreover, while the decline in union density appeared to level out during the latter years of the boom, there has been a steady decline since the recession, to just 16 per cent in 2014 .

Union density was always much higher in the public sector, at almost 70 per cent in the early years of the twenty-first century. Union density held up during the early years of the crisis but went into decline after 2011. The stability of union density in the early years of the crisis may reflect the effects of compositional changes in public-sector employment - with reductions in less organised, temporary workers offsetting the effects of voluntary redundancies among older employees who would have been more likely to be union members. However, after the imposition of pay cuts, union density began to decline steadily to a low point of 63 per cent in 2014. The imposition of pay cuts by legislation in 2009 may have indicated the impotence of trade unions during the crisis, while union agreement to pay cuts in the Lansdowne Road Agreement may have further undermined support among members or potential members.

\subsection{Industrial Relations Institutions}

With social dialogue fragmenting and union density in decline, state institutions governing wage-setting and dispute resolution also came under pressure for change. The national minimum wage (NMW) was established in Ireland by legislation in 2000 covering many low-paid workers, bringing Ireland into line with practice in many other European countries. The introductory rate of the NMW was $€ 7.65$ per hour, with lower rates for teenagers ( 70 per cent) and adults in the first year of a job ( 80 per cent). The rate 
had increased to $€ 8.65$ in 2007 , just before the crisis hit. The rate was reduced by $€ 1$ as one of the labour market reforms called for under the Memorandum of Understanding governing the Troika Financial Assistance Programme in 2010 but was restored to $€ 8.65$ by the newly elected government in 2011. It has since been increased on two occasions, to $€ 9.25$ in 2017. Other wage-setting institutions were also targeted in the Memorandum. Joint Labour Committees (JLCs) were set up in the 1940s as independent wage-setting institutions to determine pay rates in certain low-wage sectors, such as agricultural labouring, catering, hairdressing, hotels, cleaning and retail. Joint Labour Committees were composed of representatives of workers and employers, with independent chairs, and the Registered Employment Agreements (REA) for each sector were implemented through Employment Regulation Orders via the Labour Court. The effect of the JLC/ REA system would have been to raise wages and reduce inequality among vulnerable workers. There have been several attempts by employers to challenge the JLC/REA system for collective bargaining and setting wages through Employment Regulation Orders. In response, these challenges were reversed by new industrial relations legislation to restore wage-setting in vulnerable low-wage sectors, although the government also introduced in 2012 an inability-to-pay clause whereby employers could be exempted from pay increases mandated by EROs if they could make the case that the business could not afford the increase. Under the Troika Memorandum, the new legislation was amended to allow employers to seek extended exemptions for over two years. Hickland and Dundon (2016) argue that the combined effects of the enhanced time frames for exemptions introduced at the behest of the Troika and the increasingly legalistic procedures underpinning the determination of JLCs have replaced collective bargaining and negotiation with a form of legal arbitration. This would have the effect of reducing the scope of collective bargaining in low-wage sectors characterised by low levels of union density and render attempts at union organisation more challenging.

A further reform of labour market institutions concerned with employment rights and collective bargaining implemented under the auspices of the Troika Memorandum in order to improve the efficiency of Irish industrial relations institutions was the Workplace Relations Commission (WRC) in 2011. The WRC took over the functions of: the Labour Relations Commission, responsible for dispute resolution; the Employment Appeals Tribunal, governing unfair dismissals; the National Employment Rights Authority, which supervises employers' compliance with employment rights legislation; and the Equality Tribunal, which adjudicates on cases of alleged discrimination under Irish equality legislation. Under the reform, the Labour Court has become the single appeal body for all decisions by the institutions under the umbrella of the WRC. Roche and Gormley (2018) note that the WRC and the Labour Court, in attempting to resolve pay disputes, have tended to respect the 2 per cent norms established in other companies and sectors, thus providing institutional support and legitimacy to the emerging forms of coordination. Institutional support for the more widespread proliferation of the 2 per cent pay norm also facilitated convergence with European wage trends and inflation targets and supported competitiveness. 


\section{LABOUR MARKET OUTCOMES}

\subsection{Overall Employment and Unemployment}

Figure 6.2 shows employment rates for the period immediately preceding the Recession, 2007 to 2016. It is useful to consider the Irish experience in comparative perspective. The figure shows the average for the 28 EU countries, and for eight countries, including Ireland. There are three countries on the southern European periphery, Greece, Spain and Portugal, where welfare policies are relatively undeveloped, and all of which experienced severe crises in the Recession. Latvia is included as an example of an Eastern European country that also experienced a deep recession and fiscal crisis. Sweden is used as an example of a Social Democratic regime, characterised by principles of universalism and redistribution through generous social welfare benefits and inclusive services. Belgium serves as an example of a corporatist regime, where there is less emphasis on redistribution and access to entitlements is based on labour market linkages. The United Kingdom is another liberal regime, which, like Ireland, relies more heavily on targeted welfare payments and on market provision of welfare services.

In Ireland, total employment contracted by 14 per cent during the Recession, from 2008 to 2012, with the result that the employment rate fell from 69 per cent of the population aged 15-64 years in 2007, when it was above the EU28 average of 65 per cent, to 59 per cent in 2012, when the EU average was 64 per cent. The recovery in Ireland has brought the employment rate back to 65 per cent, still well short of the pre-recession peak and below the EU average. That recovery was driven by the dynamic export sector associated with FDI: maintaining competitiveness in these sectors may have been facilitated by the 2 per cent strategy adopted by trade unions in pharmaceuticals, electronics and other

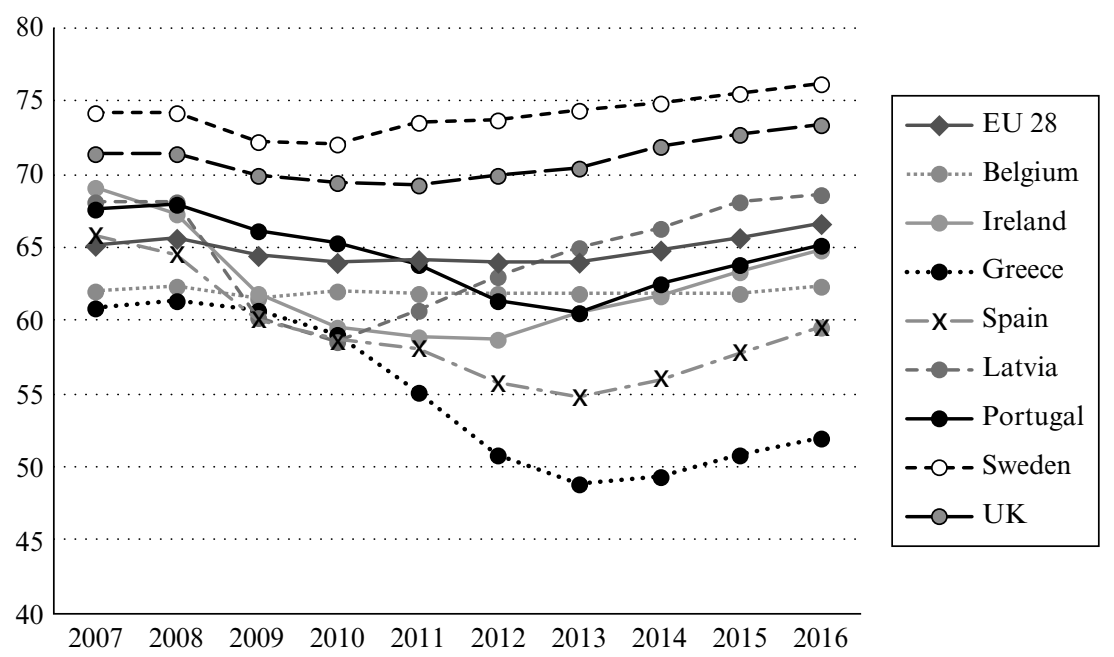

Source: Eurostat database.

Figure 6.2 Employment rates as a percentage of the population aged 15-64 years, Ireland and selected countries, 2007-16 
profitable sectors, discussed in section 3.1. However, the decline in the Irish employment rate was much less severe than in Greece, where the rate fell from a comparative low of 61 per cent to less than 50 per cent in 2013, or in Spain, where the rate fell from 66 per cent in 2007 to less than 55 per cent in 2013. There have been signs of some recovery in employment in both Greece and Spain in recent years, but their employment rates remain well below pre-crisis levels and below the European average. In Portugal, which also experienced a visit from the Troika, the employment rate fell less dramatically than in Ireland and, since 2012, employment rates in the two countries have risen in tandem. Latvia experienced a rapid employment decline in the early years of the Recession, but the employment rate has climbed steadily since 2010 and now exceeds the pre-crisis level, and the EU average. There is no evidence of a cyclical pattern to employment rates in Belgium, which has been close to 62 per cent throughout the period. Sweden and the United Kingdom, notwithstanding their differences in welfare regime, both maintain high employment rates that fell at the beginning of the Recession, between 2009 and 2011 , but both countries - which are outside the euro zone - recovered quickly and employment grew after 2012, increasing to well above the EU average in 2016.

Figure 6.3 shows unemployment rates from 2007 to 2016. In Ireland, unemployment increased from less than 5 per cent in 2007, when it was the lowest of the countries considered here, to 15 per cent in 2012, falling back to 8 per cent in 2016, and further to 6 per cent in 2018. Greece and Spain were the two countries worst affected by the Recession: unemployment increased to almost 28 per cent in Greece and 26 per cent in Spain in 2013. Unemployment remained chronically high in both countries in 2016. Portugal exhibits a similar pattern to Ireland, with unemployment steadily increasing to over 16 per cent in 2013, although the subsequent decline in unemployment has been rather less fortuitous.

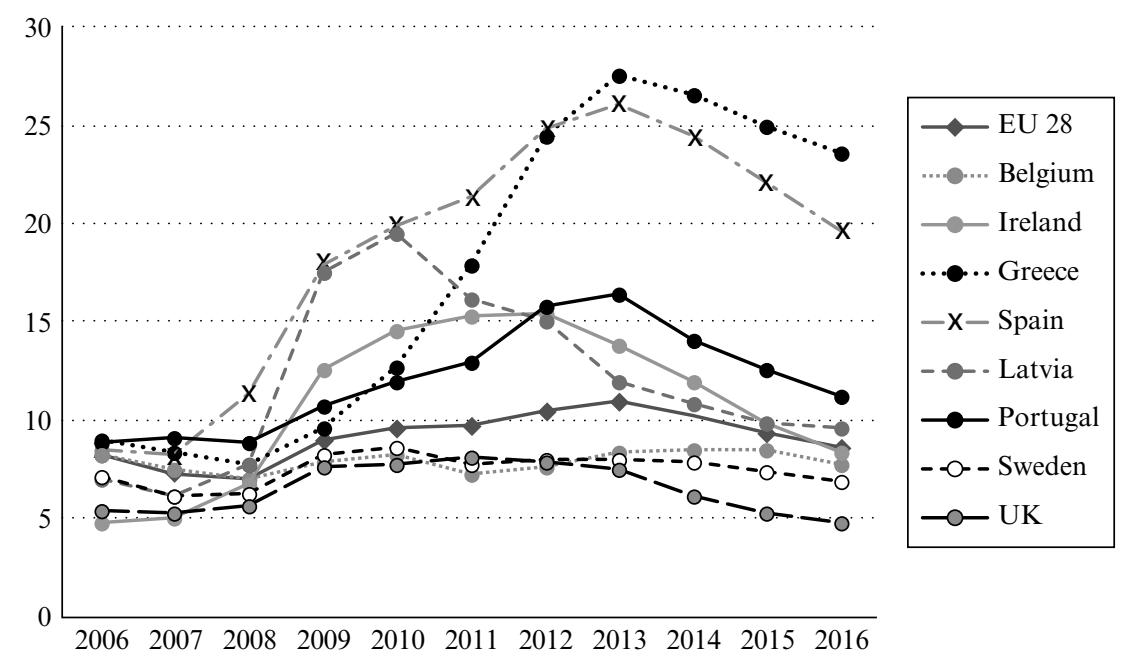

Source: Eurostat database.

Figure 6.3 Unemployment rates as a percentage of the population aged 15-64 years, Ireland and selected countries, 2006-16 
Belgium, Sweden and the United Kingdom all saw relatively modest increases in unemployment, with unemployment rates persisting in the former two for an extended period after the Recession, whereas unemployment in the United Kingdom dropped below 5 per cent in 2016. There is little support here for the contention that austerity policies had a positive impact on the labour market: most of the countries that imposed austerity saw dramatic increases in unemployment.

\subsection{Job Quality}

It is useful to consider the quality as well as the quantity of employment. Table 6.1 shows trends in average earnings by economic sector between 2011 and 2016. There was little movement in average wages over the five-year period, although there was substantial variation around the national average.

Earnings fell over the period, in public administration and defence, education, and human health and social work, most of which involve public-sector employment; even during 2015-16, in a buoyant economy and labour market, average earnings continued to fall in two of these three sectors. These are also the sectors in which union density is generally higher than in the private sector; so union membership did not safeguard workers from pay cuts in the Recession. Earnings increased sharply in the information and communication sector, where skills shortages have been experienced. Average earnings have also increased - to a lesser extent - in wholesale and retail trade, a sector characterised by low average wage levels, and in professional, scientific and technical activities.

Figure 6.4 shows comparative data on mean hourly earnings in the business economy for the years 2006, 2010 and 2014. There are huge differences in earnings between countries, from a high of $€ 18.40$ per hour in Ireland to a low of $€ 6.59$ in Latvia. There

Table 6.1 Average hourly earnings by economic sector, Ireland, 2011, 2015 and 2016

\begin{tabular}{lccccc}
\hline Principal activity & 2011 & 2015 & 2016 & $\begin{array}{c}\text { Annual } \\
\text { change } \\
(2015-16)\end{array}$ & $\begin{array}{c}\text { Five year } \\
\text { change } \\
(2011-16)\end{array}$ \\
\hline Industry & & & & 1.2 & 4.4 \\
Construction & 21.47 & 22.15 & 22.41 & 1.6 & 4.1 \\
Wholesale and retail trade & 19.06 & 19.54 & 19.85 & 2.1 & 7.1 \\
Transportation and storage & 16.66 & 17.47 & 17.84 & 3.2 & 6.0 \\
Accommodation and food & 19.82 & 20.35 & 21.01 & 2.0 & -0.1 \\
Information and communication & 12.48 & 12.23 & 12.47 & 0.3 & 11.0 \\
Financial, insurance, real estate & 26.80 & 29.65 & 29.74 & 0.9 & 1.3 \\
Professional, scientific, technical & 29.28 & 29.40 & 29.66 & 3.1 & 5.5 \\
Administrative and support services & 24.07 & 24.63 & 25.40 & 1.9 & 4.7 \\
Public administration and defence & 26.17 & 17.01 & 17.33 & -1.2 & -3.6 \\
Education & 36.62 & 34.15 & 33.84 & -0.9 & -7.6 \\
Human health and social work & 23.53 & 22.04 & 22.13 & 0.4 & -5.9 \\
Arts, entertainment, recreation and & 16.07 & 16.99 & 16.69 & -1.8 & 3.9 \\
$\quad$ other services & & & & & \\
Total & 21.94 & 21.90 & 22.04 & 0.6 & 0.5 \\
\hline
\end{tabular}




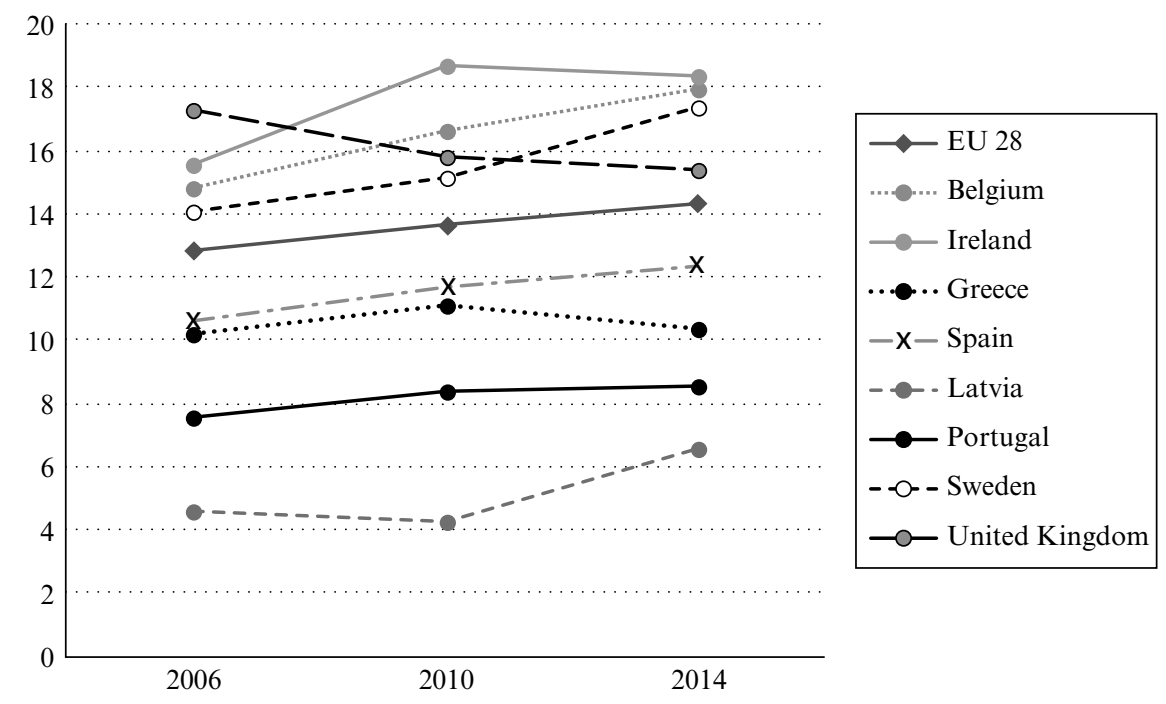

Source: Structure of Earnings Survey, Eurostat.

Figure 6.4 Mean hourly earnings in the business economy, Ireland and selected countries, 2006, 2010 and 2014 (euros, adjusted for purchasing power)

is a great deal of continuity in hourly earnings; most countries maintained their rank position, with the exception of the United Kingdom, which was the only country to experience a decline in average earnings over the entire period, and which, as a result, fell from the top of the average earnings table. In Ireland, a high-wage country, and Portugal, a relatively low-wage country, earnings increased between 2006 and 2010, which included the end of the boom as well as the recession, and were then generally flat between 2010 and 2014. There was a decline in average earnings in Greece between 2010 and 2014. In Belgium and Sweden, high earnings increased steadily over the period. The recovery in Latvia was accompanied by a substantial increase in earnings, albeit from a low base.

Another indicator of job quality is the proportion of low-wage workers and Ireland is regarded as a country with a high incidence of low pay. Collins (2015) shows that 25 per cent of employees earned less than $€ 12.20$ per hour in 2013, the Eurostat low-pay threshold of two-thirds of the median. By this measure Ireland has one of the highest rates of low pay in the OECD and its incidence has been rising almost continuously since 2000 (TASC 2015). Low pay is most common among women and young workers, in particular in sectors such as wholesale and retail trade, accommodation and food, administration and support services, and agriculture, forestry and fishing. These tend to be sectors with low levels of union membership, and in the absence of unions, wages of many workers in these sectors are set by wage-setting institutions, including the NMW and the JLC/REA system described in section 3.3 .

Figure 6.5 shows the incidence of low-wage workers in comparative perspective over the years 2006 to 2014. Latvia has a very high incidence of low-wage workers: 31 per cent of employees were earning two-thirds of the median in 2006 and this fell to 25 per cent in 


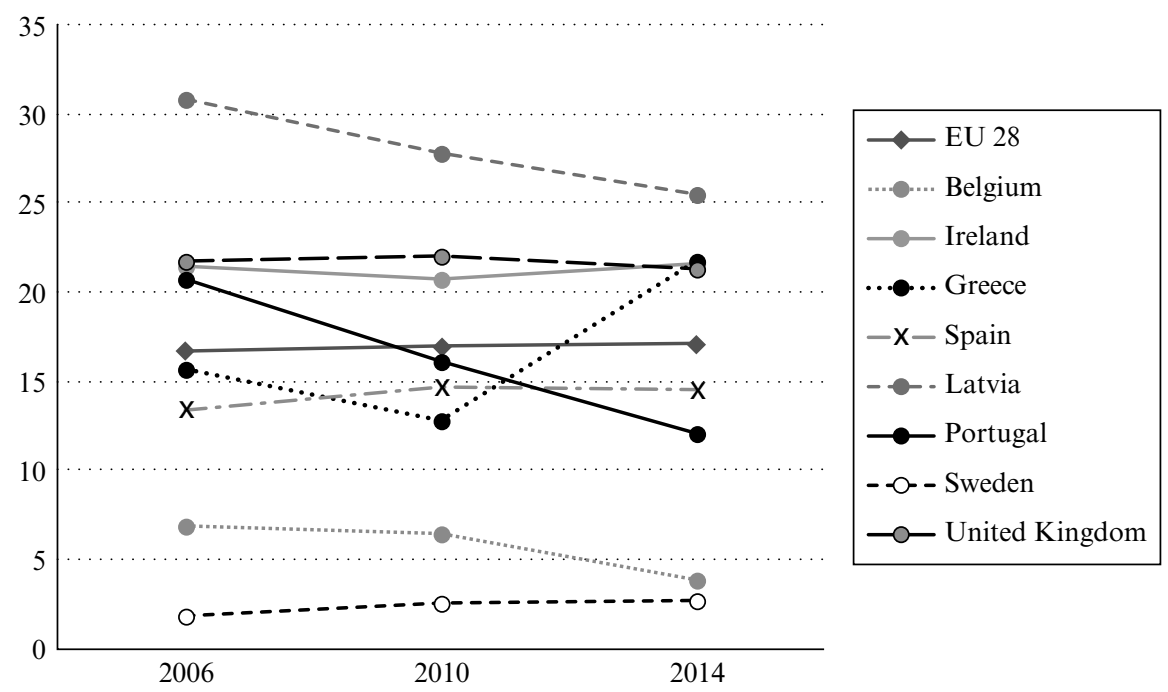

Source: Structure of Earnings Survey, Eurostat.

Figure 6.5 Low-wage workers as a percentage of all employees, Ireland and selected countries, 2006, 2010 and 2014

2016, still substantially higher than the EU average of 17 per cent. Ireland and the United Kingdom, both liberal market economies, have relatively high proportions of workers on low wages - about 22 per cent - and this has changed little over time. The incidence of low-wage workers climbed sharply in Greece after 2010, to about the Irish and UK level. However, in Portugal - another southern European peripheral country - the incidence of low wages dropped from 21 per cent (about the Irish rate) in 2006 to 12 per cent in 2014, at which point it was well below the EU average. Sweden and Belgium show much greater levels of equality, with very low proportions of workers in low-wage jobs.

The Irish Central Statistics Office (CSO) began collecting a new data series on recipients of the NMW in Ireland in 2016. The CSO (2017b) report shows that 10 per cent of employees earned the NMW, then set at $€ 9.15$ per hour. About 9.3 per cent of male employees and 10.9 per cent of females earned the NMW or less. Age differences were particularly marked: 42 per cent of employees in the 15-24 age group earned the NMW or less, compared with 10 per cent of those aged 25-34 and 5.6 per cent of those aged 35-44. Almost 38 per cent of all those earning the NMW were in the 15-24 age group. Almost three out of five employees ( 58.5 per cent) at or below the NMW worked part-time, and almost 27 per cent of part-timers were earned the NMW or less. Immigrants, who tend to show much lower levels of unionisation than the native-born population, were also much more likely to be at or under the NMW: 17 per cent of non-Irish employees, compared with 9 per cent of Irish employees. 


\subsection{Atypical Working}

The incidence of part-time working increased in Ireland during the Recession, from about 19 per cent of total employment in 2008 to 24 per cent in 2012. Underemployment, referring to those part-time workers who indicated that they were willing and available to work additional hours, increased more sharply, doubling their share of total employment from just under 4 per cent to just under 8 per cent of all employees. The vast majority of part-time workers are women: part-time working among women increased by about 12 per cent during the Recession and in 2012 almost one in 10 women at work reported that they were underemployed, willing to work more. Among men the increase in part-time working was more marked: there was a 48 per cent increase, albeit from a much lower base. Also, the rate of involuntary part-time working among men increased from 2.6 per cent to 6.6 per cent of total employment. Part-time working has declined during the recovery, although it remains elevated relative to the level before the Recession. The share of involuntary part-time working has also decreased, although it also remained somewhat higher in 2016 (3.6 per cent) than it had been in 2008 ( 2.6 per cent) among men.

Over the course of the Recession and its immediate aftermath, Irish patterns of parttime working increased from about the EU average in 2007 to close to the level found in countries such as Belgium, Sweden and the United Kingdom, where part-time working is more common. Figure 6.6 shows that after the recovery, levels of part-time working in Ireland have remained above the EU average. Part-time working has also increased, albeit from a lower base, in the other countries hit hard by the Recession: Greece, Portugal and Spain, and in recent years, Latvia.

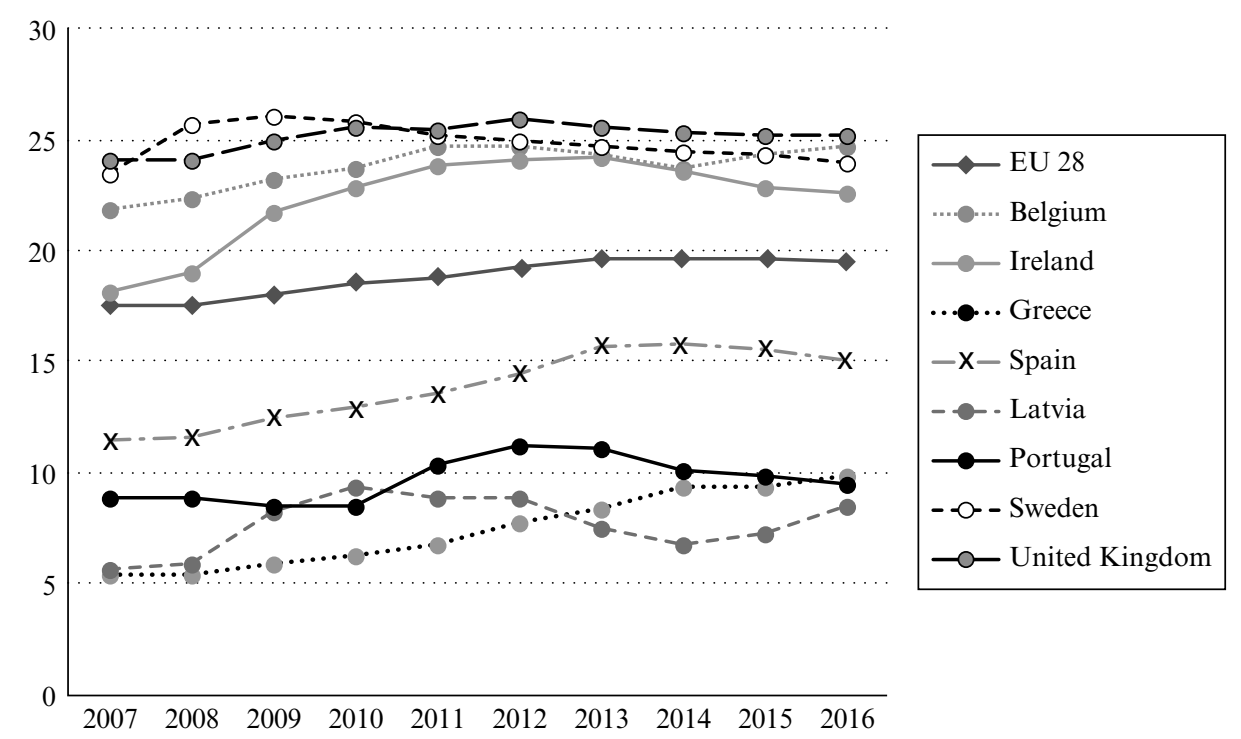

Source: Eurostat database.

Figure 6.6 Part-time as a percentage of total employment, Ireland and selected countries, 2007-16 
Given the relatively high degree of flexibility in the Irish labour market, and the weakness of employment protection regulations, it is perhaps not surprising that temporary contracts are not a prominent feature in Ireland. Relatively weak employment protection regulations, which themselves may reflect the limited influence of collective bargaining, mean that employers do not face significant barriers or costs associated with firing employees, so they are less likely to resort to fixed-term contracts. By a similar logic, temporary contracts do not fluctuate greatly with macroeconomic conditions. Nevertheless, analysis of the Quarterly National Household Survey (QNHS) shows that temporary contracts among employees aged 15-64 years increased from 8.6 per cent in 2006, during the boom, to 10 per cent in 2012, in the depths of the Recession. Since then, temporary working has fallen to 7 per cent in 2017. Kelly and Barrett (2017) show that new entrants to jobs during the Recession were more likely to be working part-time or on temporary contracts, and that this trend was not fully reversed during the recovery in 2014 and 2015. Figure 6.7 shows that, in comparative terms, the incidence of temporary contracts is well below the EU average. Within the groups of countries that share this characteristic, both Ireland and Latvia saw their incidence of temporary contracts increase during the Recession and then subside during the recovery. In two of the other countries that experienced deep crises, Greece and Portugal, there is little evidence of an impact of the crisis on temporary working. In Spain, where temporary contracts have been an important part of the labour market, temporary working fell steadily during the decline in overall employment between 2009 and 2013 and increased as total employment recovered. This pro-cyclical pattern would suggest that those on temporary contracts are more exposed to shifts in labour demand in Spain than in the other crisis countries.

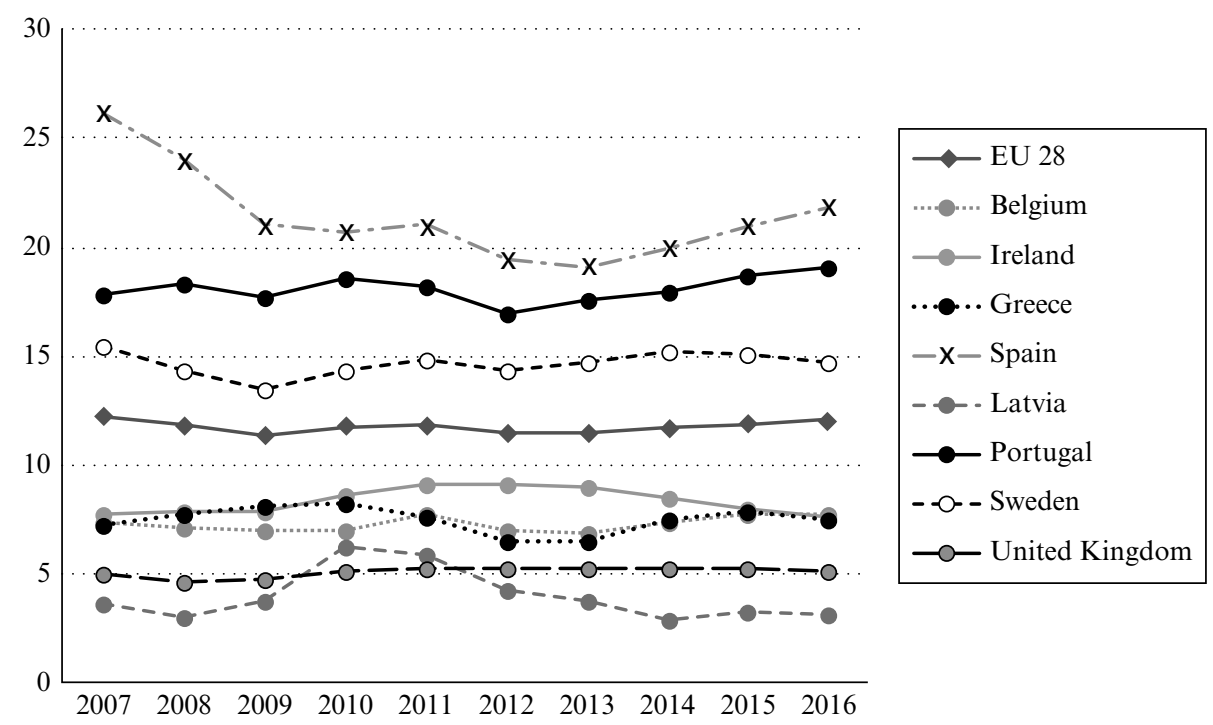

Source: Eurostat database.

Figure 6.7 Temporary contracts as a percentage of total employment, Ireland and selected countries, 2007-16 


\section{INEQUALITY AND WELFARE POLICY}

Inequality of market incomes, already high during the boom period, increased during the Recession, driven in particular by the surge in unemployment and its concentration among those who had been employed in low-skill, low-wage and exposed sectors, as well as by cuts in the wages and working hours of those still in work. Table 6.2 shows that, by 2015 , inequality of market incomes had fallen somewhat, but not to pre-recession levels.

We noted previously that Ireland can be characterised as a liberal welfare regime, with welfare policies dominated by market provision, and with low rates of social expenditure and means-tested targeted benefits. Austerity measures introduced during the Recession led to cuts in social welfare payments. Among the unemployed, for example, rate cuts in jobseeker payments in 2009 and 2010 amounted to 10 per cent of the 2008 levels; the Christmas bonus payment, which amounted to an extra week's payment, was abolished; payment rates for those under 25 years of age were cut by up to 50 per cent; eligibility and entitlement criteria were tightened up, and the duration of insurance-related jobseeker payments was reduced (Murphy 2017). These cuts were imposed following the collapse of Social Partnership, so the manner in which austerity was implemented was not directly influenced by collective bargaining. Notwithstanding the austerity cuts, social welfare transfers and taxes achieved substantial reductions in market-generated inequality and their impact was particularly strong during the Recession, reducing the Gini coefficient from 0.59 with regard to market incomes to 0.32 in respect of disposable incomes in the depths of the recession of 2013. The strong role of taxes and transfers in reducing market inequalities was achieved despite increased taxes and cutbacks in social welfare payment levels to working age welfare recipients implemented under austerity policies after 2009, as well as in the context of the EU/IMF Programme. Highly redistributive state social expenditures would seem to have survived the demise of social partnership agreements, although given that the development of the social protection system had been influenced by the social partners over the previous two decades, this continuity may be seen as a legacy of Social Partnership.

Figure 6.8 shows the ratio of total disposable income received by the 20 per cent of the population with the highest income to that received by the 20 per cent of the population with the lowest income (lowest quintile). Disposable income is gross income from all sources plus state transfer payments and minus direct taxes, such as income taxes and social security contributions. The data relate to household incomes after the state has

Table 6.2 Household income inequality for market and disposable incomes, and impact of taxes and social transfers, Ireland, 2008, 2013 and 2015

\begin{tabular}{lccc}
\hline & 2008 & 2013 & 2015 \\
\hline Market & & Gini coefficient & \\
Disposable & 0.52 & 0.59 & 0.56 \\
& 0.31 & 0.32 & 0.31 \\
Taxes & & Reynolds-Smolensky Index & \\
Transfers & 0.05 & 0.07 & 0.07 \\
\hline
\end{tabular}

Source: $\quad$ Savage et al. (2018). 


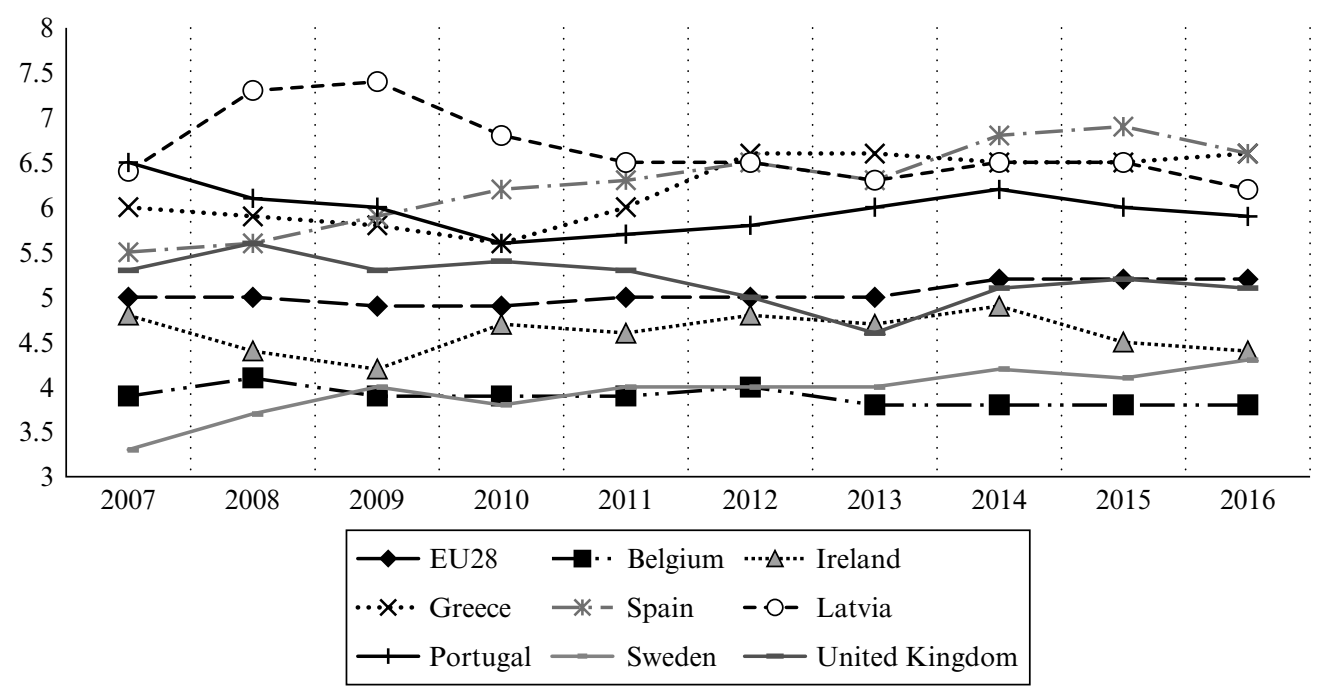

Source: Eurostat, EU-SILC.

Figure 6.8 Ratio of disposable income received by the top 20 per cent of households to that received by the bottom 20 per cent, Ireland and selected countries, 2007-16

modified inequalities generated in the market, but do not take account of the impact of state services, such as housing and health. In Ireland, just before the Recession, the disposable income of the eightieth quintile was just under five times that of the twentieth quintile, close to the EU average at that time. By this measure, income inequality was a good deal higher in Ireland than in Belgium and Sweden, but lower than in the United Kingdom, and much lower than in Portugal, Greece and Latvia. During the early years of the Recession, the ratio between the top and the bottom income quintiles fell in Ireland as higher-income groups suffered proportionately greater income cuts than lower-income groups, partly because the latter's incomes were preserved by social welfare incomes. This decline in inequality also occurred in Greece and Portugal, but inequality increased in the other countries deeply affected by crisis, Latvia and Spain. Since the Recession the Irish pattern of inequality has differed from the other crisis countries: by 2016 the top-to-bottom household income ratio was at or above 6 in Greece, Spain, Latvia and Portugal, but it was 4.3 in Ireland, at which point it was on a par with Sweden, which had seen inequality increase steadily over the decade. Here again, the strong redistributive impact of the Irish state might be regarded as partly a legacy of the previous two decades of Social Partnership.

\section{CASE STUDY: YOUNG PEOPLE IN THE LABOUR MARKET}

Young people in Ireland were hit particularly hard by the Recession and benefited little from the early years of recovery (Kelly et al. 2014). Table 6.3 shows that employment of those aged 15-24 contracted by over 50 per cent between 2007 and 2012, an extraordinary 
Table 6.3 Employment, unemployment and labour force participation by age group, Ireland, 2007, 2012 and 2016 (Q4)

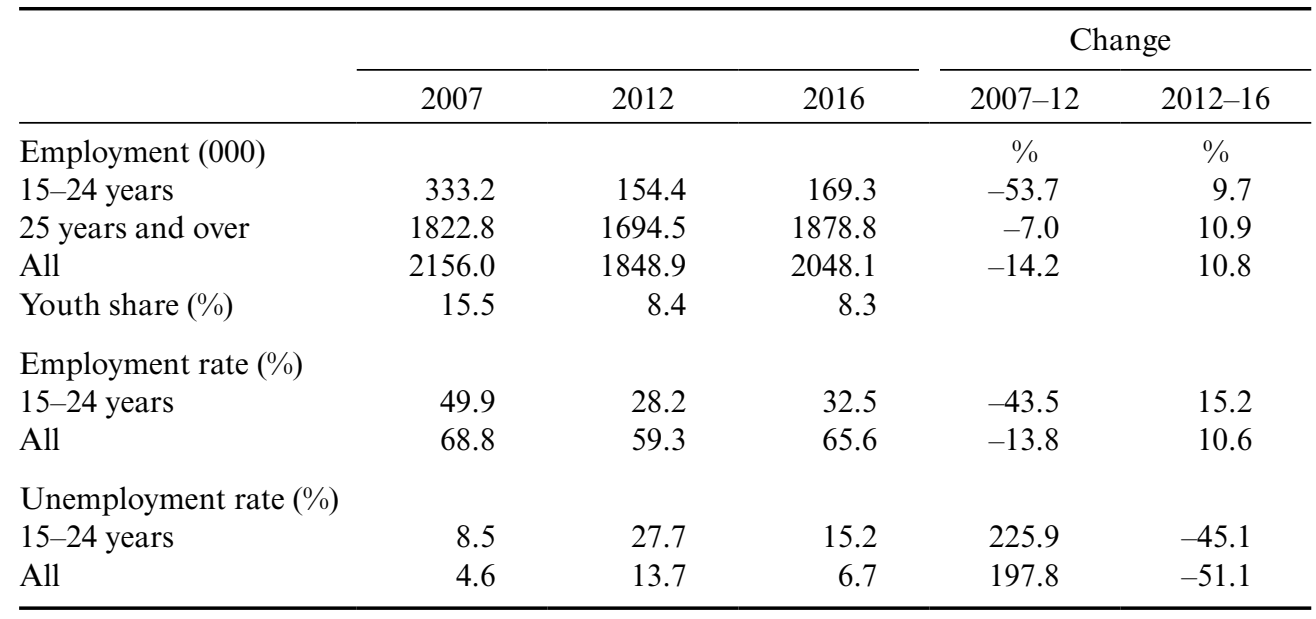

Source: QNHS, various years.

closing off of opportunities and labour market entry points for young people (O'Connell 2017). Unemployment among young people reached almost 30 per cent in the depths of the Recession and about 10 per cent of the young cohort are estimated to have emigrated during that time. While employment among those aged over 25 began to increase with economic growth in 2013, employment among young people continued to decline through 2015 and began to show signs of growth only at the beginning of 2016. There was strong growth in the employment of young people during 2016, with the result that the job growth over the period of recovery in 2012-16 among young people (9.7 per cent) almost matched that among the older age groups (10.9 per cent). However, by the end of 2016 the employment rate among young people (32.5 per cent) remained far below its pre-recession peak of 50 per cent.

The growth in employment in recent years suggests an improvement in the labour market, notwithstanding the contraction in the labour market for young people and the continuing disparity between employment and unemployment rates of young people compared with their older siblings and parents. Less is known about the quality of jobs created during the recovery, nor about differences in the quality of jobs for young people compared with their older counterparts. Conefrey and Smith (2014) show that there was a significant decline in starting salaries for new graduates between 2008 and 2014, and we show below that young people are substantially less likely than their older peers to be in unionised jobs. Microdata from the QNHS allow us to look at several indicators of the extent and distribution of atypical employment arrangements in 2006 during the boom, in 2012 in the Recession, and in 2016 during the recovery.

Figure 6.9 shows that, before the Recession, well over half the population aged 15-24 was in employment in Ireland and the United Kingdom, both of which were well above the EU average of less than 40 per cent. Youth employment contracted sharply during the Recession, a trend also followed in each of the countries deeply affected by the economic 


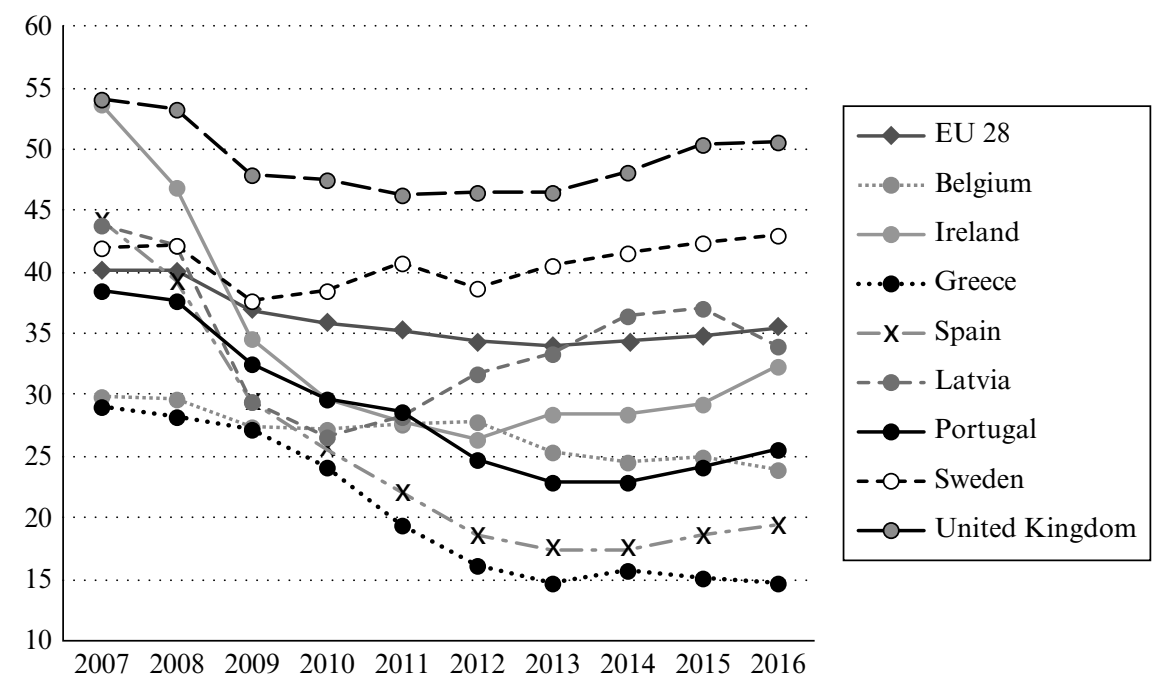

Source: Eurostat database.

Figure 6.9 Youth employment rates: population aged 15-24, Ireland and selected countries, 2007-16

and financial crisis: Greece, Spain, Portugal and Latvia. There has been some growth in youth employment in recent years, except in the case of Greece, but in all of the crisis countries where youth employment plummeted, it remained well below pre-crisis levels. In the Irish case, this meant that the employment rate converged with the EU average in 2016, although this is an inauspicious form of convergence.

Youth unemployment has long been a problem of concern to policy-makers across Europe. Figure 6.10 shows that, during the Recession and its aftermath, youth unemployment soared to exceptional and alarming levels, at over 55 per cent of young labour market participants, in Greece and Spain, and to over 35 per cent in Latvia and Portugal. Youth unemployment increased to over 30 per cent in Ireland in 2012, although this was ameliorated by strong outward migration, a feature of Ireland that is not shared by the other crisis countries (Glynn and O'Connell 2017). Youth unemployment has declined in all of the countries considered here, since about 2013, although Ireland and Latvia are the only two crisis countries in which youth unemployment had fallen to about the EU average by 2016. This may also reflect a more active approach to tackling youth unemployment in these two countries.

Another useful indicator of young peoples' integration in the labour market is the percentage not in employment, education or training (NEET), a group that is particularly problematic because it is neither economically active nor preparing for economic activity. Figure 6.11 shows that, prior to the Recession, most countries clustered around the EU average, with NEETs accounting for about 14 per cent of the 15-34 age group. Greece had a higher incidence (17 per cent) and Sweden a lower one ( 8 per cent). The percentage of NEETS increased in most countries during the Recession, sharply in Greece and Spain, and to a lesser extent in Ireland and Latvia, suggesting employment and training systems 


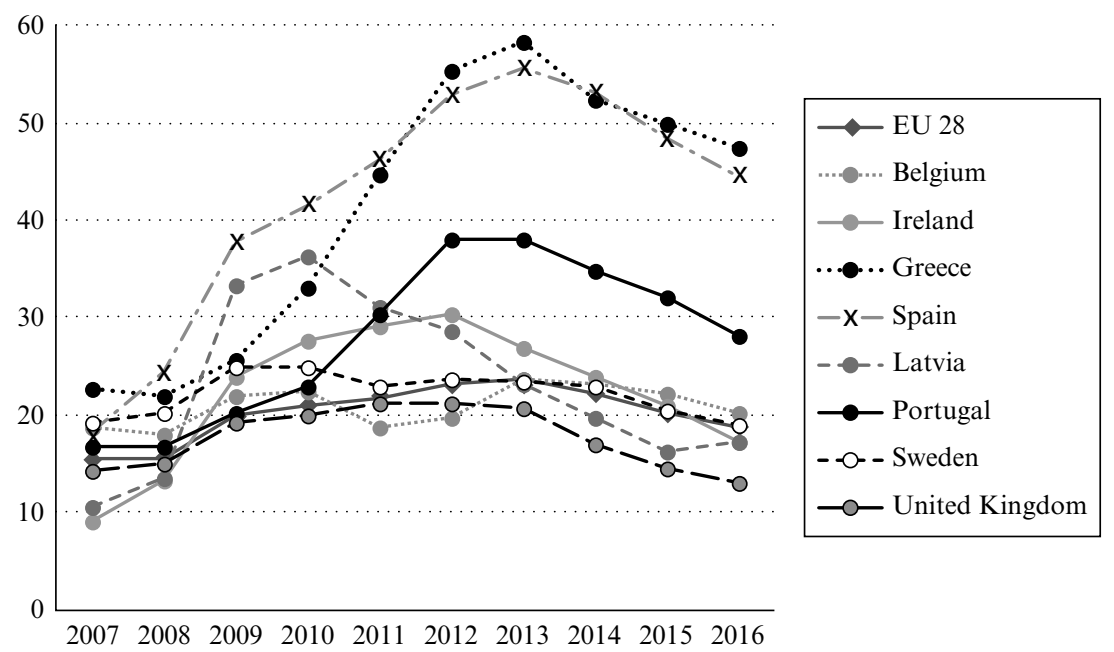

Source: Eurostat database.

Figure 6.10 Youth unemployment rates: population aged 15-24, Ireland and selected countries, 2007-16

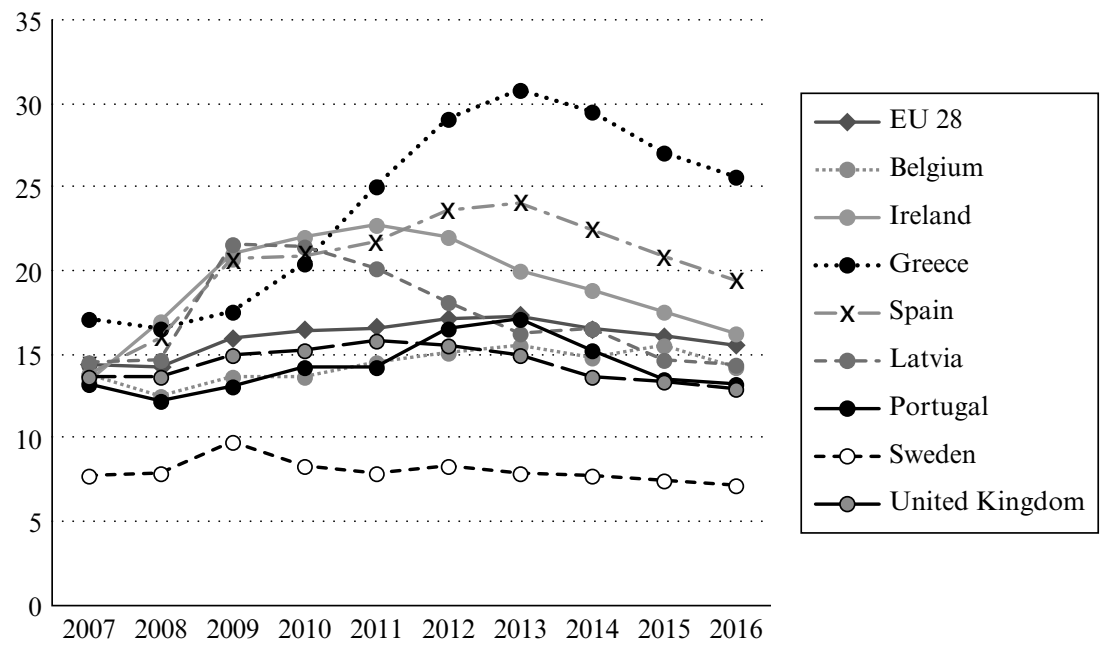

Source: Eurostat database.

Figure 6.11 Percentage of young people aged 15-24 not in employment, education or training, EU28, 2007-16 


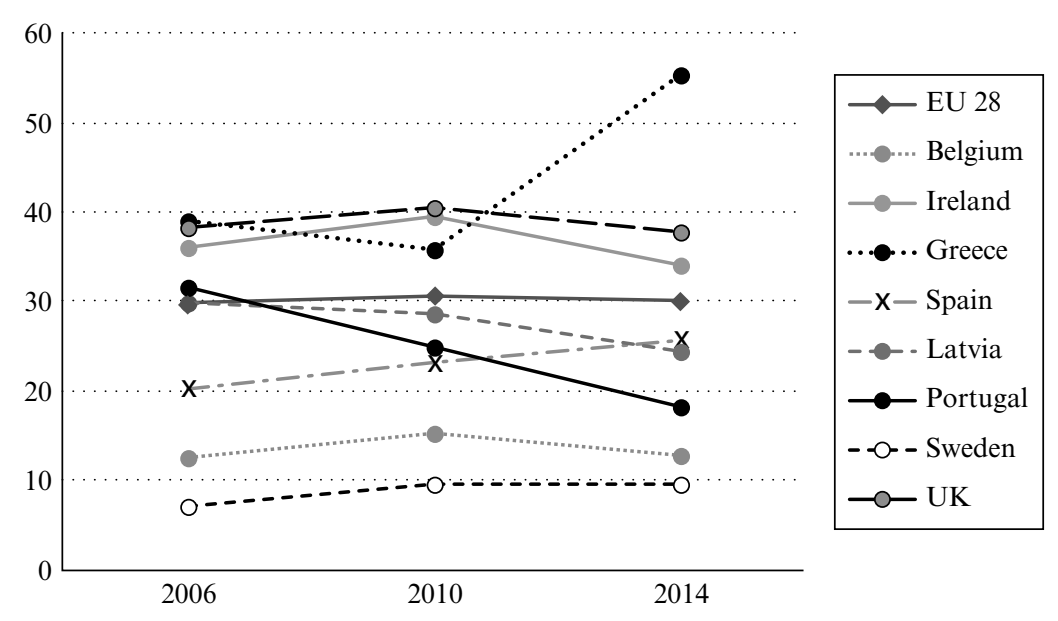

Source: Structure of Earnings Survey, Eurostat.

Figure 6.12 Low-wage workers as a proportion of all employees aged 15-30, Ireland and EU28, 2006, 2010 and 2014

that were ill prepared for the labour market downturn. The proportion of NEETS has fallen in most countries, following the decline in unemployment. Greece and Spain still suffer from elevated NEET levels, while Ireland and Latvia have converged with the EU average. In the Irish case that is also partly due to increased retention of young people in mainstream education.

What about the quality of jobs worked by young people? Throughout Europe about 30 per cent of young employees are in low-wage jobs, earning less than two-thirds of the country median. ${ }^{2}$ Figure 6.12 shows that Ireland, along with its neighbour the United Kingdom, another liberal market economy with low union density and collective bargaining coverage, has a higher share of young, low-wage workers; around 40 per cent in 2010. That share fell somewhat between 2010 and 2014, but remained above the EU average. The proportion of young, low-wage workers increased dramatically in Greece, to 55 per cent, and while it increased in Spain it was still below the EU average in 2016. In two other crisis countries, Latvia and Portugal, the proportion of young, low-wage workers declined. Increased inequality between young and older workers is not an inevitable consequence of recession and austerity.

Table 6.4 shows part-time working by age group in Ireland. Young people often take part-time jobs, frequently combining education with work. In 2006 almost 25 per cent of those in the 15-24 age group worked part-time, compared with an overall average of 18 per cent of all employees. By 2012 the proportion of the youngest cohort of employees who were at work had doubled, to over 48 per cent. Part-time working generally increased during the Recession, but among the older age groups the increase was modest, at 6 percentage points overall.

By the second quarter of 2017, after five years of recovery, part-time working had fallen to 21 per cent, still appreciably higher than before the Recession, suggesting that 
Table 6.4 Part-time working by age group, Ireland, 2006, 2012 and 2017 (Q2) (percentage)

\begin{tabular}{lccc}
\hline & 2006 & 2012 & 2017 \\
\hline Age 15-24 & 23.1 & 48.3 & 40.6 \\
Age 25-34 & 10.5 & 16.9 & 14.1 \\
Age 35-44 & 18.3 & 22.9 & 17.4 \\
Age 45-54 & 21.3 & 21.2 & 21.8 \\
Age 55-64 & 27.0 & 32.8 & 29.8 \\
All & 18.0 & 24.4 & 21.4 \\
\hline
\end{tabular}

Source: Author's analysis of QNHS micro-data.

Table 6.5 Percentage of employees working part-time, by age-group and sex, Ireland, 2017 (percentage)

\begin{tabular}{lccc}
\hline & Male & Female & All \\
\hline Age 15-24 & 33.1 & 48.0 & 40.6 \\
Age 25-64 & 8.6 & 29.8 & 19.4 \\
All & 10.9 & 31.5 & 21.4 \\
\hline
\end{tabular}

Source: Author's analysis of QNHS micro-data.

the recovery is incomplete and that the new employment is of lower quality than before the recession. Union membership declined over the course of the Recession and recovery, and that decline was particularly marked among younger workers. Part-time employment among young people remained over 40 per cent, substantially higher than among any of the older age groups and much higher than was observed among young people before the Recession. Almost 40 per cent of young people working part-time in 2012 were underemployed. They wanted and were available to work longer hours, and this proportion had dropped to 24 per cent in $2017 .^{3}$

There are marked gender differences in part-time working. Table 6.5 shows that women are much more likely to work part-time than are men. In 2017 almost half of all young women employees in 2017 were working part-time, compared with one-third of young men. Employees in the youngest age group were much more likely to work part-time and the age differential was much more marked among young men.

Young people are also generally more likely than older people to be on temporary or fixed-term contracts as they attempt to settle into the labour market. Table 6.6 shows that, in 2006, during the boom, almost 20 per cent of young employees were on temporary contracts, compared with an overall average of 8 per cent. During the Recession, the proportion of young employees on temporary contracts increased sharply, to 34 per cent, while the proportion of the older age groups increased by a few percentage points, at most. By 2017, the pattern of temporary employment had returned to pre-recession levels for most employees. Indeed, overall the incidence of temporary working declined to 7 per cent, below the pre-recession average. However, 26 per cent of employees in the 
Table 6.6 Temporary employment contracts by age group, Ireland, 2006, 2012 and 2017 (Q2) (percentage)

\begin{tabular}{lccc}
\hline & 2006 & 2012 & 2017 \\
\hline Age 15-24 & 19.5 & 34.3 & 26.4 \\
Age 25-34 & 6.8 & 10.1 & 6.3 \\
Age 35-44 & 4.1 & 6.4 & 4.3 \\
Age 45-54 & 4.2 & 6.1 & 4.3 \\
Age 55-64 & 5.9 & 6.0 & 5.1 \\
All & 7.9 & 10.2 & 7.0 \\
\hline
\end{tabular}

Source: Author's analysis of QNHS micro-data.

Table 6.7 Employees combining both part-time and temporary employment contracts by age group, Ireland, 2006, 2012 and 2017 (Q2) (percentage)

\begin{tabular}{lrrr}
\hline & 2006 & 2012 & 2017 \\
\hline Age 15-24 & 10.5 & 24.1 & 18.4 \\
Age 25-34 & 1.9 & 4.2 & 2.5 \\
Age 35-44 & 1.9 & 3.5 & 2.0 \\
Age 45-54 & 2.5 & 3.6 & 2.5 \\
Age 55-64 & 4.1 & 4.6 & 4.2 \\
All & 3.8 & 5.9 & 4.1 \\
\hline
\end{tabular}

Source: Author's analysis of QNHS micro-data.

15-24-year age group were on temporary contracts in 2017, higher than before the recession and substantially higher than older employees.

In order to identify employees with particularly atypical arrangements, Table 6.7 looks at the proportion of employees combining part-time working with temporary contracts. About 4 per cent of employees are found in this disadvantaged group of employees, although that increased to 6 per cent during the Recession. However, this group accounted for one in ten young employees in 2006 and this climbed to one in four in 2012. In the context of recovery, over 18 per cent of young people in employment work part-time on temporary contracts, much higher than among older workers and far higher than before the Recession.

Another indicator of atypical employment arrangements is working unsocial hours. Table 6.8 shows the proportion of employees who usually work evenings, nights or Sundays, all working times that can clash with family and personal life. The proportion of all employees working unsocial hours increased from 15 per cent to almost 26 per cent between 2006 and 2012, but in the recovery that proportion has remained relatively high, at 21 per cent. Following the now familiar pattern, the incidence of unsocial hours increased particularly strongly among young people, from 21 per cent in 2006 to 46.5 per cent in 2012, and it remained elevated, at just under 40 per cent in 2017 in the context of recovery, far higher than before the Recession, and far higher than the incidence among 
Table 6.8 Employees who usually work evenings, nights or Sundays by age group, Ireland, 2006, 2012 and 2017 (Q2) (percentage)

\begin{tabular}{llll}
\hline & 2006 & 2012 & 2017 \\
\hline Age 15-24 & 21.3 & 46.5 & 39.8 \\
Age 25-34 & 15.3 & 26.2 & 23.0 \\
Age 35-44 & 13.7 & 22.6 & 19.0 \\
Age 45-54 & 13.3 & 22.1 & 18.0 \\
Age 55-64 & 12.5 & 19.7 & 15.3 \\
All & 15.4 & 25.6 & 21.3 \\
\hline
\end{tabular}

Source: Author's analysis of QNHS micro-data.

Table 6.9 Union membership of employees by age group, Ireland, 2006, 2012 and 2017 (Q2) percentage)

\begin{tabular}{lrrr}
\hline & 2006 & 2012 & 2017 \\
\hline Age 15-24 & 13.5 & 9.5 & 6.8 \\
Age 25-34 & 27.1 & 24.8 & 16.9 \\
Age 35-44 & 38.5 & 33.8 & 27.5 \\
Age 45-54 & 47.3 & 42.2 & 31.8 \\
Age 55-64 & 43.7 & 42.2 & 40.1 \\
All & 32.4 & 31.3 & 25.5 \\
\hline
\end{tabular}

Source: Author's analysis of QNHS micro-data.

all older workers. It is difficult to avoid the conclusion that working conditions for young workers might be better if they were working in unionised jobs.

Another indicator of job quality is union membership. We have already seen that union density has been falling in Ireland throughout the twenty-first century. That pattern is confirmed in Table 6.9, which shows the percentage of employees who reported that they were members of a union holding up during the Recession, but falling from 31 per cent in 2012 to 25 per cent in 2017. This would suggest that much of the growth in employment during the recovery was in non-union jobs.

While we see a decline in union membership across all age groups, there is a particularly marked decline among the younger age groups. By 2017, less than 7 per cent of employees aged 15-24 were union members, as were 17 per cent of those in the 25-34 age group. We have observed a consistent declining trend in the quality of jobs and working conditions for young people, a trend that coincides with the marked decline in their union membership.

\section{CONCLUSIONS}

Prior to the Recession, Ireland was distinctive in European terms as a liberal market economy, characterised by: high levels of inequality and labour market flexibility; low 
union density and collective bargaining coverage and weak employment protection; and a liberal welfare state with low levels of (means-tested) social welfare transfers. Since the Recession, Ireland has achieved a strong but incomplete recovery and retains key characteristics that distinguish it from European norms. Departure of the United Kingdom from the EU would be likely to enhance Ireland's distinctiveness within Europe.

One of the immediate casualties of the Recession and the fiscal crisis of the Irish state was the collapse of national collective bargaining arrangements under Social Partnership. In the absence of Social Partnership, public-sector workers saw their wages slashed and private sector workers lost their jobs. A possible legacy of social partnership, however, may have been an enduring commitment to reducing high levels of market-generated inequalities with targeted social transfers that survived the fiscal discipline imposed by the EU-ECB-IMF Troika.

After the Recession, economic and employment growth has been accompanied by continued decline in union density and in collective bargaining coverage. The international literature would suggest that the Recession led to greater decentralisation of pay bargaining in a disorganised manner that compromised the capacity of unions to represent their members and coordinate pay bargaining. However, in Ireland the resumption of collective bargaining in the public sector, and the development of pattern bargaining in the private sector in the context of economic recovery, suggests some continuity, and a degree of coordination in social dialogue, a departure from the experience of other European crisis countries that Roche and Gormley (2017) term 'orderly decentralisation'. As the recovery gathers pace, however, signs are emerging of growing demands for pay increases in the private sector that may undermine the coordinated approach observed in pattern bargaining between 2011 and 2016. Demands have also emerged from public service unions for additional pay and allowances, and this may reflect wider public service pressure for pay increases beyond those agreed in the public-sector agreements. If these pressures intensify, this may result in a return to more decentralised patterns of bargaining in private-sector firms and fragmentation in the public sector, with strategically placed groups of workers pressing their claims.

In terms of labour market outcomes, the Irish recovery remains incomplete. Before the Recession the Irish employment rate was well ahead of the European average, but in 2016, after four years of economic growth, the employment rate remained short of the pre-recession peak and below the EU average. Recovery brought a substantial decline in unemployment, with the result that the Irish unemployment rate fell to 8 per cent, thus converging with the EU average, and falling below that in later years.

Average wages are comparatively high in Ireland, similar to levels in Belgium and Sweden, and well above the EU average. However, the proportion of workers in low-wage jobs is also high, similar to the proportion in the United Kingdom, another liberal market economy, and to Greece, which has seen a sharp rise in earnings inequality over the course of its deep and prolonged economic crisis.

While these high levels of inequality in market incomes prevailed throughout the past decade in Ireland, they were substantially reduced by social transfers, despite austerity policies. As a consequence, the inequality in distribution of disposable income is comparatively low. After the Recession, the ratio of disposable income received by the top 20 per cent of households to that received by the bottom 20 per cent was similar to the level in Sweden, a Social Democratic country with a strong commitment to equality, and well 
below levels of inequality in four other countries that experienced deep recession: Spain, Greece, Latvia and Portugal. In this respect Ireland diverged in a positive manner from the EU average inequality, which increased gradually over the years 2007 to 2016.

Young people in Ireland were hit particularly hard by the Recession and the period of economic recovery has seen greater polarisation between younger and older workers. Younger workers in Ireland are less likely to be in union jobs, and much more likely to work part-time hours, temporary contracts and unsocial hours than are older workers.

In comparative terms, the collapse of the youth labour market meant that the employment rate of young people moved from substantially greater than the EU average to below it, that is, negative convergence. On a more positive note, youth unemployment fell sharply with economic recovery, leading to positive convergence with the European average, and, again, divergence from the experience of other crisis countries: Greece, Spain and Portugal.

Ireland, together with its liberal market neighbour the United Kingdom, has a very high proportion of young workers on low wages and the incidence of low-wage working fell slightly between 2010 and 2014, thus achieving a modicum of convergence with a static EU average.

Young workers are entering employment on inferior terms and conditions than their older peers. These trends are likely driven by the complex interplay of factors that include economic restructuring, globalisation and increased competition, new technology and the growth of non-standard forms of employment and economic activity. However, it is also the case that young workers have been affected particularly strongly by the decline in union membership and collective bargaining coverage. If union membership were higher among young workers, then their working conditions might improve, suggesting opportunities for greater mobilisation efforts on the part of unions in Ireland.

\section{NOTES}

1. Averaged across the 15 pre-enlargement member states.

2. The data exclude apprentices.

3. This indicator of underemployment was not collected in the QNHS until 2008, so we cannot measure the extent of underemployment before the Great Recession.

\section{REFERENCES}

Baccaro, L. and M. Simoni (2002), 'Centralized wage bargaining and the "Celtic Tiger" phenomenon', Industrial Relations, 46 (3), 426-55.

Barry, F. and A. Bergin (2017), 'Business', in W. Roche, P. O'Connell and A. Prothero (eds), Austerity and Recovery in Ireland: Europe's Poster Child and the Great Recession, Oxford: Oxford University Press, pp. 63-84.

Central Statistics Office (CSO) (2017a), 'Historical earnings 1938-2015', CSO, Cork.

Central Statistics Office (CSO) (2017b), 'QNHS: National Minimum Wage Estimates Quarter 2-Quarter 4 2016', CSO, Cork.

Collins, M. (2015), 'Earnings and low pay in the Republic of Ireland: a profile and some policy issues', Working Paper No WP 2015/29, Nevin Economic Research Institute, Dublin.

Conefrey, T. and R. Smith (2014), 'On the slide? Salary scales for new graduates 2004-2012', Economic Letters Series, Central Bank of Ireland, no. 1, 1-6. 
Department of Public Expenditure and Reform (DPER) (2014), Public Service Reform Plan, 2014-2016, Dublin: DPER.

Eurostat (various years), 'European Union Structure of Earnings Survey', accessed 2 January 2019 at https://ec.europa.eu/eurostat/web/microdata/structure-of-earnings-survey.

FitzGerald, J. (2000), 'The story of Ireland's failure - and belated success', in B. Nolan, P. O'Connell and C. Whelan (eds), Bust to Boom? The Irish Experience of Growth and Inequality, Dublin: Institute of Public Administration, pp. 27-57.

Glynn, I. and P. O'Connell (2017), 'Migration', in W. Roche, P. O'Connell and A. Prothero (eds), Austerity and Recovery in Ireland: Europe's Poster Child and the Great Recession, Oxford: Oxford University Press, pp. 290-310.

Hickland, E. and T. Dundon (2016), 'Reform of joint regulation and labour market policy during the current crisis: the manufacturing sector in the Republic of Ireland', in A. Koukiadaki, I. Távora and M. Martínez Lucio (eds), Joint Regulation and Labour Market Policy During the Crisis, Brussels: ETUI, pp. 205-56.

Honohan, P. and B. Walsh (2002), 'Catching up with the leaders: the Irish hare', Brookings Papers on Economic Activity, 33 (1), 1-78.

Kelly, E. and A. Barrett (2017), 'Recent developments in the Irish labour market: is it all good news?', IZA Discussion Paper No. 10541, Institute of Labour Economics, Bonn.

Kelly, E., S. McGuinness, P. O'Connell, D. Haugh and A. González Pandiella (2014), 'Transitions In and Out of Unemployment among Young People in the Irish Recession', Comparative Economic Studies, 56 (4), 616-34.

Kinsella, S. (2017), 'Economic and Fiscal Policy', in W. Roche, P. O'Connell and A. Prothero (eds), Austerity and Recovery in Ireland: Europe's Poster Child and the Great Recession, Oxford: Oxford University Press, pp.40-61.

Koukiadaki, A., I. Távora and M. Martínez Lucio (eds), (2016), Joint Regulation and Labour Market Policy during the Crisis, Brussels: ETUI.

MacCarthaigh, M. (2017), Public Sector Reform in Ireland: Countering Crisis, London: Palgrave Macmillan.

McGuinness, S., E. Kelly and P. O'Connell (2010), 'The impact of wage bargaining regime on firmlevel competitiveness and wage inequality: the case of Ireland', Industrial Relations: A Journal of Economy and Society, 49 (4), 593-615.

Murphy, M. (2017), 'Irish flex-insecurity: the post-crisis reality for vulnerable workers in Ireland', Social Policy and Administration, 51 (2), 308-27.

Nolan, B. and B. Maitre (2007), 'Middle incomes in boom and bust: the Irish experience', in D. Vaughan-Whitehead (ed.), Europe's Disappearing Middle Class: Evidence from the World of Work, Cheltenham, UK and Northampton, MA, USA: Edward Elgar and Geneva: ILO, pp. 323-59.

O'Connell, P. (2013), 'Cautious adjustment in a context of economic collapse: the public sector in the Irish crisis', in D. Vaughan-Whitehead (ed.), Public Sector Shock: The Impact of Policy Retrenchment in Europe, Cheltenham, UK and Northampton, MA, USA: Edward Elgar and Geneva: ILO, pp. 337-70.

O'Connell, P. (2017), 'Unemployment and labour market policy', in W. Roche, P. O'Connell and A. Prothero (eds), Austerity and Recovery in Ireland: Europe's Poster Child and the Great Recession, Oxford: Oxford University Press, ch. 13.

Organisation for Economic Co-operation and Development (OECD) (2018), OECD Economic Surveys: Ireland, Paris: OECD.

Regan, A. (2012), 'The impact of the eurozone crisis on Irish Social Partnership: a political economy analysis', DIALOGUE Working Paper No. 3, International Labour Office, Geneva.

Roche, W. (2017), 'Workplaces', in W. Roche, P. O'Connell and A. Prothero (eds), Austerity and Recovery in Ireland: Europe's Poster Child and the Great Recession, Oxford: Oxford University Press, pp. 194-213.

Roche, W. and T. Gormley (2017), 'The durability of coordinated bargaining: crisis, recovery and pay fixing in Ireland', Economic and Industrial Democracy accessed 2 January 2019 at https://doi. org/10.1177/0143831X17718067.

Roche, W. and T. Gormley (2018), 'The advent of pattern bargaining in Irish industrial relations', Industrial Relations Journal, 48 (5-6), 442-62. 
Roche, W. and P. Teague (2015), 'Antecedents of concession bargaining in the Great Recession: evidence from Ireland', Industrial Relations Journal, 46 (5-6), 434- 45.

Roche, W., P. O'Connell and A. Prothero (2017), 'Introduction: "“poster child” or beautiful freak? Austerity and recovery in Ireland', in W. Roche (ed.), Austerity and Recovery in Ireland: Europe's Poster Child and the Great Recession, Oxford: Oxford University Press, pp. 1-22.

Savage, M., T. Callan, B. Nolan and B. Colgan (2018), 'The Great Recession, austerity and inequality: evidence from Ireland', Review of Income and Wealth, accessed 2 January 2019 at https:// onlinelibrary.wiley.com/doi/abs/10.1111/roiw.12337.

Think-tank for Action on Social Change (TASC) (2015), 'Low Pay Commission: submission on the National Minimum Wage', March, TASC, Dublin.

Visser, J., S. Hayter and R. Gammarano (2015), 'Trends in collective bargaining coverage: stability, erosion or decline?' Labour Relations and Collective Bargaining, Issue Brief No. 1, International Labour Office, Geneva.

Walsh, F. (2014), 'Union membership in Ireland since 2003', Journal of the Statistical and Social Inquiry Society of Ireland, 44, 86-100. 